\title{
Konektivitasi Hate Speech, Hoaks, Media Mainstream dan Pengaruhnya Bagi Sosial Islam Indonesia
}

\author{
Luqman Al Hakim \\ Universitas Islam Negeri Sunan Kalijaga \\ 20201022003@student.uin-suka.ac.id \\ Said Hafif Anshori \\ Universitas Islam Negeri Sunan Kalijaga \\ 20201022011@student.uin-suka.ac.id
}

\begin{abstract}
This article aims to explain the connections between hate speech, hoaxes, mainstream media with impact on Indonesian Social Islam. the article will explain the role media in developing in the social field, and technology until giving new perusal, in problems in related actual issues until becoming rich perspective and understand information. The mapping in this paper is described from the 2014 Presidential Election to the issues that have been circulating recently, including the development of the dynamics of Indonesian Islam. The solutions presented in this paper are; the role of parents in controlling their children and early social media education. This must be done because the current generation is a generation that is aware of technology, thus it is appropriate to educate based on the needs of the times. There are results found that there are deficiencies in understanding and applying social media so that it often creates anxiety that starts from the virtual world and then is brought to the real world or vice versa from the real world to the virtual world.
\end{abstract}

Key Words: Media, Indonesian Islam, and Hoax.

\begin{abstract}
Abstrak
Tulisan ini membahas keterkaitan hate speech, hoaks, media mainstream serta dampaknya bagi Sosial Islam Indonesia. di dalamnya akan mengulas peran media dalam perkembangan di ranah sosial, dan teknologi sehingga memberikan pembacaan baru, dalam permasalahan-permasalahan yang berkaitan dengan isu-isu aktual sehingga menjadikan kaya akan prespektif, dan melek informasi. Pemetaan di tulisan ini diuraikan mulai Pilihan Presiden 2014 hingga isu-isu yang beredar akhir ini termasuk perkembangan dinamika Islam Indonesia. Adapun pemecahan yang disuguhkan dalam tulisan ini, yakni; peran orang tua dalam mengontrol anak mereka, dan pendidikan media sosial sejak dini. Hal tersebut dilakukan sebab generasi saat ini merupakan generasi yang sudah melek teknologi dengan demikian sudah sepantasnya didik berdasarkan kebutuhan zaman yang ada. Terdapat hasil yang ditemukan yakni terjadi kekurangan dalam memahami dan
\end{abstract}


mengaplikasikan media sosial sehingga seringkali memunculkan keresahan yang bermula dari dunia maya kemudian dibawa ke dunia nyata maupun sebaliknya dari dunia nyata dibawa ke dunia maya.

Kata Kunci: Media, Islam Indonesia, dan Hoaks.

\section{Pendahuluan}

Membahas agama dan media dalam prespektif Hoover dan Lundby, berkaitan dengan pengkajian tiga asas teori agama, teori budaya, dan teori media. Tiga teori tersebut penting diamati secara utuh dan saling terkait (interrelated web) antara satu dengan lainnya. ${ }^{1}$ Dengan dipandu tiga teori tersebut akan memudahkan memahami media dan agama sehingga dalam pembacaannya akan memberikan penafsiran dari berbagai sudut.

Komunikasi merupakan peroses menyalurkan pesan dan informasi agar mudah dipahami. Komunikasi bertujuan menciptakan kesetaraan, keadilan, keharmonisan hubungan dan kedamaian hidup yang sejati. Munculnya globalisasi menjadi tantangan komunikasi dengan perkembangan media terjadi percabangan dalam berkomunikasi bukan hanya memperoleh kebaikan bersama, akan tetapi sebagai sarana hate speech, penyebaran hoaks, dan perpecahan di kalangan masyarakat yang termanifestasikan sebagai media mainstream, penyebaran pengaruh disegala bidang seperti penayangan kampanye calon tertentu baik dalam tingkat daerah dan negara. Pengaruh media dalam menayangkan aksi demonstrasi massa di tengah gejolak politik yang memanas akibat krisis ekonomi, memberikan ketegangan sosial kemasyarakatan. ${ }^{2}$

Globalisasi media menciptakan penyempitan dunia dengan perjalanan lebih cepat, negara-negara mampu dijelajahi dalam hitungan jam bukan hari masyarakat berbagai wilayah menjadi seperti keluarga yang besar. Akses informasi semakin cepat berita di lokasi yang jauh diketahui dalam hitungan detik dan menit, keadaan tersebut menjadi nilai yang positif dan negatif jika berita tersebut hoaks akan memberikan citra yang buruk. Situasi ini disebut sebagai bentuk cyber mind yang memberikan pembatas pada ranah sosial. Sering menimbulkan perpecahan contohnya dalam konteks pilpres 2014 dan 2019 umat Muslim terpecah akibat berbagai program media mainstream. ${ }^{3}$

\footnotetext{
1 Amin Abdullah, "Hermeneutika Islam Dan Budaya Populer," in Kitab Suci dan Para Pembacanya, 1st ed. (Yogyakarta: Stelkendo Kreatif, 2019), 13.

${ }^{2}$ Nuraini Soyomukti, Komunikasi Politik. Kudeta Media Analisa Komunikasi Rakyat \& Penguasa (Malang: Intrans Publishing, 2013), 2.

3 David Holmes, Teori Komunikasi Media, Teknologi, dan Masyarakat (Yogyakarta: Pustaka Pelajar, 2012), 309-401.
} 
Penelitian terdahulu yang diteliti oleh Mulawarman dan Aldila Dyas Nurfitri membahas perilaku bermedia sosial beserta implikasinya ditinjau dari psikologi sosial terapan, pembahasan media sosial pada riset ini hanya menampilkan sisi positif akan tetapi belum menampilkan aspek kekurangan dan analisis kejadian fakta bermedia sosial di lapangan hanya sebatas global belum terspesifikasi dalam lingkup yang mikro, sebab pada dasarnya setiap manusia berbeda dan harus dikalisifkasikan terhadap konsep bermedia sosialnya. Penelitian ini belum memberikan solusi dalam konteks etika bermedia sosial yang baik dan benar sehingga menimbulkan celah di dalamnya. ${ }^{4}$

Adapun penelitian yang dilakukan oleh Dian Junita Ningrum, Suryadi, dan Dian Eka Chandra Wardhana yang berjudul kajian ujaran kebencian di media sosial. Menemukan bahwa ujaran kebencian merupakan suatu ikon linguistik yang kontradiktif dengan konsep kepaduan berbahasa sebagai parameter kecerdasan linguistik dan tata susila berkomunikasi, selain itu penelitian ini juga menemukan berbagai jenis tindakan ujaran kebencian yang melibatkan kategori pelecehan, perusakan nama, memprovokasi, perbuatan yang tidak menyenangkan, penistaan agama, hoaks, dan lainnya. Adapun tindakan penilaian pertuturan ilokusi yakni asertif 32,63\%, direktif 20,63\%, komisif 9,26\%, ekspresif 35,9\%, dan deklaratif $1,58 \%$ dengan total 882 data dan tuturan dari 20 konteks tuturan. ${ }^{5}$

Hoaks menjadi permasalahan besar sebab mampu menghadirkan kesalahpahaman dan menimbulkan perpecahan dalam tatanan yang ada serta menghambat kebijakan nasional, kebijakan nasional ialah implementasi dari upaya pencapaian tujuan nasional melalui rancangan-rancangan kegiatan utama dalam konstruksi mencapai tujuan nasional tersebut. Kebijakan nasional, dinarasikan sebagai pandangan dan perilaku nasional khususnya terhadap persoalan negara. ${ }^{6}$ Penggorengan Hoaks tanpa klarifikasi dapat menghadirkan kebencian serta menimbulkan umpatan kebencian, masyarakat awam menjadi korban pertama hoaks dan ujaran kebencian disebabkan masyarakat awam belum mengetahui fakta dan opini.

Dalam politik juga ditemukan permasalahan yang serupa korban dari pemalsuan dan ucapan kebencian ialah pemilih belia. Pemilih belia masuk kategori remaja tahap akhir, kisaran usianya antara 17-21 tahun, usia ini rawan sebab masamasa mencari jati diri yang sukar dijangkiti oleh hal yang masih abstrak. Kemudian

4 Mulawarman, Aldila Dyas Nurfitri, "Perilaku Pengguna Media Sosial beserta Implikasinya Ditinjau dari Perspektif Psikologi Sosial Terapan,” Buletin Psikologi, Vol. 25, No. 1, (2017): 37, https://doi.org/10.22146/buletin psikologi.22759.

5 Dian Junita Ningrum, Suryadi, Dian Eka Chandra Wardhana,"Kajian Ujaran Kebencian Di Media Sosial, Jurnal Ilmiah Korpus, Vol. II, No. III, (2018), 241, https://ejournal.unib.ac.id/index .php/korpus/article/view/6779.

${ }^{6}$ Samsul Wahidin, Dasar-Dasar Pendidikan Pancasila dan Pendidikan Kewarganegaraan (Yogyakarta: Pustaka Pelajar, 2018), 191. 
diusia tersebut penggunaan media sosial relatif tinggi karena mereka menemukan aspek-aspek yang baru, sehingga peran orang tua besar dalam mengarahkan perilaku bermedia sosial yang bijak dan sehat. Ujaran kebencian ialah segala tindakan ekspresi verbal dan non-verbal, yang mempublikasi hasutan, mempromosikan atau melegalkan kebencian yang dilandaskan oleh sikap intoleransi dan dasar agama. Merebaknya profokasi kebencian salah satunya disebabkan karena negara terlambat memberikan respon melalui peraturan-peraturannya bagi pertumbuhan teknologi informasi, khususnya media masa yang melahirkan aneka ujaran kebencian. ${ }^{7}$

Adapun tujuan penelitian ini yakni, untuk mengetahui bagaimana konektivitasi (keterkaitan) antara hoaks, hate speech, dan dampaknya bagi umat Islam Indonesia. Hasil dari penelitian ini menemukan hadirnya keterkaitan antara hoaks, hate speech dan dampak demoralisasi ditubuh umat Islam, yang diolah dan dikemas oleh media dalam bentuk hoaks dan hate speech, dinarasikan pada masyarakat sehingga muncul kebencian, dalam tubuh umat Islam sendiri sudah terpecah terdapat golongan mudah terprofokasi dan sulit terprofokasi sehingga menimbulkan lost conceptions diinternal muslim.

Adapun perbedaan Penelitian dari penelitian terdahulu yakni, menjelaskan konteks keterkaitan perpecahan umat Islam Indonesia dengan melihat secara nasional dan internasional. Nasional dengan mengamati perkembangan media cetak, media pers, dan media sosial. Banyak menghancurkan hubungan sesama Islam dengan memakai hujatan yang disiarkan oleh media saluran swasta, kemudian dengan meningkatnya hate space yang dimuat di media sosial baik berupa Facebook, Instagram, dan bloger-bloger. Salah satu institute internasional yang menyoroti Indonesia yakni Lowy Institute Australia dengan menerbitkan buku Man of Contradictions: Joko Widodo and the Struggle to Remake Indonesia pada September 2020.

Sedangkan Pendekatan yang digunakan pada penelitian ini ialah pendekatan sosial keagamaan yang membahas sebuah penampakan secara berakar melalui tinjauan opini media sosial dan mengumpulkan data. metode kualitatif menjadi salah satu alat yang aplikasilan dalam penelitian yang berbasis sosial keagamaan selain menggunakan metode kuantitatif. Kajian ini menghasilkan solusi dalam bermedia sosial serta perlu untuk menyaring dan mengklarifikasi informasi yang masuk, meminimalisir hate speech dengan menjelaskan fakta yang terjadi di lapangan disertai dengan bukti dan sumber yang valid, dan berusaha tetap netral dalam menyikapi permasalahan dalam sosial umat Islam dan dapat mengambil keputusan yang objektif, awal memudarnya hubungan umat Islam Indonesia dari Pilpres 2014 yang

${ }^{7}$ Lusia Astrika, Yuwanto, "Ujaran Kebencian dan Hoaks: Signifikasinya terhadap Pemilih Pemula di Kota Semarang," JIIP: Jurnal Ilmiah Ilmu Pemerintahan, Vol. 4, No. 2, (2019): 109. 
menjadikan saling mencurigai dan menghujat sehingga memunculkan istilah-istilah kasar.

\section{Hasil Dan Pembahasan}

\section{Narasi Hate speech, Hoaks dan Permasalahan Bangsa}

Meningkatnya penggunaan media sosial memacu hadirnya evolusi pada bentuk identitas masyarakat gyber dan bentuk penyaluran informasi yang dimasa kini dipetakkan dalam media tradisional. Kebebasan berbicara dan berekspresi dilandaskan dengan adanya perundang-undangan yang mengizinkan setiap individu memiliki otonom untuk memperoleh hak beraspirasi yang mendasar, salah satunya kebebasan dalam berkomunikasi. Nitizen memiliki kendali atas pembuatan dan penyaluran informasi, dengan mencari informasi yang diinginkan. Fenomena tersebut menjadikan kebebasan dalam mencari informasi yang beredar di kalangan umum, ${ }^{8}$ sehingga terjadi penyebaran informasi dan terjadi penyelewangan dalam beberapa kasus bermedia sosial, dalam praktiknya terdapat contoh perbuatan tidak baik yang dilakukan nitizen atau media mainstream yang menyulut perpecahan.

Akan tetapi dalam praktiknya tidak seluruh masyarakat peka dalam mencari kebenaran informasi, kebanyakan dari mereka percaya, membagikan berita tersebut, dan meluapkan emosi sebagai bentuk ujaran kebencian di media sosial, kebebasan berpendapat menjadi salah satu alasan masyarakat meluapkan emosi di media sosial, secara yuridis sebagai warga terdapat undang-undang bebas berpendapat dan berekspresi akan tetapi dalam konteks tersebut perlu ditelaah perbuatan tersebut merugikan atau tidak. Pemerintah memberikan respon dengan mengeluarkan UU ITE yang bertujuan untuk menyaring informasi, mengurangi dominasi hoaks dan hate speech yang mewabah di media sosial.

Independensi bersuara telah disusun dalam hukum Indonesia dan hukum internasional Pasal 29 Deklarasi Universal Hak Asasi Manusia dan UUD 1945 pasal 28. Hak bersuara tercermin melalui komunikasi verbal maupun nonverbal. Tercatat pada website Sekertariat Kabinet Republik Indonesia, pemakai internet berjumlah 132,7 juta atau 52\% dari total masyarakat Indonesia. Dari angka tersebut, terdapat 129,2 juta memiliki akun aktif. Umumnya pengguna tersebut menggunakan waktu 3 jam sehari untuk mengkonsumsi. ${ }^{9}$

Mengingat angka besar di atas tentu peran media sosial sebagai agen of change besar, serta mampu menggiring opini dan lebih jauh lagi sehingga muncul

${ }^{8}$ Dewi Maria Herawati, "Penyebaran Hoax Dan Hate Speech Sebagai Representasi Kebebasan Berpendapat," Promedika: Public Relation Dan Media Komunikasi, Vol. 2, No. 2, (2016), 141, https://doi.org/10.52447/ promedia.v2i2.793.

9 Ibid., 140. 
hoaks, dan menciptakan hate speech demi kepentingan perseorangan atau segelintir golongan dan mengorbankan masyarakat secara masal. ${ }^{10}$ Peran agama dalam kehidupan manusia tidak dapat lepas dari kemauan sentral dalam jiwa, yakni selalu mencari sesuatu yang berada di luar dirinya, nampak, serta mampu mengerti hatinya. Secara alamiah baik manusia, hewan dan tumbuhan senantiasa ingin hidup secara kodrati, setiap manusia memiliki sikap ingin dipuja dan memuja, dalam konsespsi tersebut media mampu memasuki ruang lingkup hati manusia dan memberikan dorongan motivasi untuk mempercayai informasi atau tidak. Dalam memaknai media, hoaks dan hate speech dapat melibatkan pemaknaan agama yang mendalam sebab agama memiliki fungsi sebagai penyaring perbuatan sehari-hari. Agama merupakan suatu world view di dalamnya berisikan aneka kepercayaan serta hadir melalui gagasan pikiran manusia baik dalam bentuk budaya, serta keyakinan akan nilai supranatural. ${ }^{11}$

Bangsa Indonesia ialah bangsa yang agamis dan menjunjung tinggi nilai agama. Dalam menyelesaikan permasalahan bangsa negara terjadi keterlibatan agama secara tidak langsung terjadi penyisipan nilai agama dalam konsepsi wawasan nusantara yang memperkokoh persatuan dan kesatuan masyarakat Indonesia. Wawasan nusantara sebagai corak dalam melihat bangsa Indonesia tentang identitas dan alamnya yang dilandasi Pancasila disusun dalam rangka mencapai tujuan nasional. ${ }^{12}$

Keragaman Indonesia baik suku, etnis, budaya, dan agama. memberikan ciri kekhasan dan perbedaan, dengan demikian terjadi perbedaan pada titik tersebut media mampu berperan demi memperkokoh persatuan besar, akan tetapi media juga mampu dalam meruntuhkan kesatuan tersebut dengan menyebarkan hoaks, isu-isu sara, kekerasan dan lain lain. Sebagaimana yang dikutip dari penelitian Dewi Maria Herawati, tentang wabah hoaks pada tahun 2017, Dalam penelitian tersebut terjadi terpaan hoaks dimana hoaks 44,30\% tercatat dalam sehari memperoleh lebih dari satu kali dalam sehari yakni 17,20\%, mendekati 12 jam sehari masyarakat diserang hoaks, secara tidak langsung terjadi konsumerisasi dalam membentuk pemikiran yang menghasilkan percaya kepada hoaks. Terdapat beberapa alasan masyarakat menerima hoaks, sebesar 40,60\% pengaruh hoaks dalam opini publik, 28,90\% merasa senang karena berita heboh,

${ }^{10}$ Secara garis besar dapat dimengerti dengan berkembangnya teknologi, media sosial mampu memberikan perubahan besar dalam masyarakat dari lini makro hingga mikro. Oleh sebab itu agama memiliki peran sebagai filter dalam menggunakan media sosial secara bijak.

11 Sofyan Hadi, Ilmu Dakwah Dari Konsep Paradigma Hingga metodologi (Jember: Center For Society Studies, 2012), 86.

12 Samsul Wahidin, 87. 
22,90\% menganggap belum ada hukuman bagi pelaku, dan 7,60\% menjadikan sebagai bisnis. ${ }^{13}$

Pada tahun 2020 di kala pandemik Corona virus (Covid 19), terjadi banyak hoaks dan ujaran kebencian sebagaimana yang dilansir dalam JawaPos.com Polda Metro Jaya masih berusaha menyingkap mengungkap segala permasalahan hoaks dan ujaran kebencian, pasalnya dari 443 kasus pada April hingga awal Mei yang terdeteksi 14 kasus yang terbongkar. Kabid Humas Polda Metro Jaya, Kombes Pol Yusri Yunus menuturkan konten-konten hoaks dan ujaran kebencian menyebar dibeberapa ruang-ruang media sosial. Adapun targetnya banyak pihak salah satunya pejabat negara. "konten-konten tindak pidana terbagi menjadi beberapa topik. Salah satu contoh yang sering seperti profokasi kebencian kepada presiden Indonesia, mengumpat Menkes, informasi palsu mengenai penutupan data tol, beberapa portal lockdown dan lainnya.

Agar tersamarkan riwayatnya, pelaku sering memakai akun fiktif, akan tetapi terdapat dari mereka yang menggunakan akun asli guna menyebarkan konten hoaks dan ujaran kebencian. Dengan tujuan membuat profokasi kepada masyarakat. Polda Metrojaya merinci 443 kasus dengan rincian, 166 kasus ditangani Direktorat Reserse Kriminal Khusus Polda Metro Jaya 51 kasus ditangani Polres Metro Jakarta Selatan, 36 Kasus ditangani Polres Metro Jakarta Barat, dan 36 kasus di tangani Polres Metro Jakarta Barat, dan 36 kasus ditangani Polres Metro Jakarta Pusat. ${ }^{14}$

Peran pemerintah untuk meminimalisir perpecahan yang disebabkan oleh hoaks, dan ujaran kebencian selain menerbitkan UU ITE juga harus melakukan komunikasi terhadap masyarakat agar masyarakat tahu mana yang benar dan yang palsu. Oleh sebab itu dibutuhkan sarana dialog yang bertugas untuk menginformasikan secara masal dengan cakupam yang besar. Dalam aturan pemerintahan, media massa memiliki beberapa peran penting, yakni;

a) Menginformasikan mengenai:

i. Aturan pemerintah

ii. Streategi mensejahterakan rakyat

iii. Status politik dalam negeri

iv. Aktivitas jalinan komunikasi dengan negara-negara lain sebagai kebijakan politik luar negeri

b) Membentuk karakter bangsa melalui fungsi pendidikan

${ }^{13}$ Herawati, "Penyebaran Hoax Dan Hate Speech Sebagai Representasi Kebebasan Berpendapat," 146.

14 Bintang Pradewi, Sabik Aji Taufan, "Kasus Hoax dan Hate Speech Covid19,Polisi:Motifnya Buat Resah Warga," https://www.google.com/amp/s /www.jawapos. $\mathrm{com} /$ nasional/hukumkriminal/05/05/2020/kasus-hoax-dan-hate-speech-covid-19-polisimotifnya-buat-resah-warga/\% 3 famp, Diakses Pada 05 Desember 2020. 
c) Melakukan fungsi sosialisasi dalam kaitan pelestarian sistem politik

d) Menumbuhkan kepercayaan negara lain melalui sajian-sajian berita yang direncanakan dan ditata dengan baik. ${ }^{15}$

\section{Media Mainstream Sebagai Ajang Sensasi}

Dewasa ini, Media menjadi kebutuhan melalui telepon pintar, setiap orang mampu membuat akun, seperti Instagram, Facebook, Twitter, Path, dan lainnya. Kondisi tersebut ialah keumuman yang merubah cara bersosialisasi di masa teknologi, evolusi dan inovasi yang terjadi dibidang teknologi memberikan dampak positif dan negatif salah satu dampaknya dengan tersebarnya pengetahuan melalui berbagai media yang memasuki kehidupan manusia. Era tersebut juga menandai munculnya perang media dengan melahirkan media mainstream yang merugikan masyarakat dari lini kecil hingga besar. Berdasarkan publikasi riset Crowdtap, Ipsos MediaCT, dan The Wall Street Journal pada tahun 2014 mengikutkan 839 narasumber antara usia 16-36 tahun memperlihatkan durasi yang digunakan dalam menggunakan media sosial sebanyak 6 jam 46 menit perhari lebih dari mengakses media tradisonal. Kandungan hasil itu memperlihatkan media tradisional sudah tidak menjadi media yang dominan diakses oleh khalayak. ${ }^{16}$

Hoaks yang ditayangkan oleh media dapat dilihat sebagai ajang sensasi negatif dengan memberikan kegaduhan dalam fakta dan temuan yang ada di lapangan. Tantangan di abad 21 (abad globalisasi) sangat besar, sebab hoaks dapat dimanifestasikan sebagai pengejawatahan pemikiran konserfatif yang menyimpang dari fakta dan temuan yang ada di lapangan. Berbagai temuan hoaks dan hate speech yang ditemukan oleh masyarakat menandakan mundurnya peradaban dan kembali ke abad kegelapan ${ }^{17}$. Rasa kehilangan arah dan pesimisme merupakan cerminan dalam realita, tidak harus selalu dalam aspek politik. Irasional yang mendominasi bukan hanya kebetulan, secara keseluruhan merupakan cerminan psikologis dunia terhadap nasib manusia yang dikendalikan oleh satu kekuatan besar yang tidak dapat terpecahkan. ${ }^{18}$

Media komunikasi dapat dianalogikan dalam konteks sosial besar yang dapat difungsikan dalam mengirim informasi, namun mampu membuktikan

15 Thomas Tokan Pureklolon, Komunikasi Politik Mempertahankan Integritas Akademisi, Politikus, dan Negarawan (Jakarta: Gramedia, 2016), 15.

16 Mulawarman, Aldila Dyas Nurfitri, 37.

17 Abad kegelapan ialah abad jahiliah kala kebenaran dan fakta dilempar dan digantikan dengan kemelaratan baik dari aspek ekonomi dan aspek nilai religious (demoralisasi) yang menggelobal menolak otoritas realitas fakta dan menerima kejumudan dan kemadekan dalam berpikir menerima oponi secara mentah tanpa melihat kesesuaian yang ada di lapangan.

18 Nuraini Soyomukti, 143. 
makna pengetahuan; bukanlah sebatas instrumen kita pada dunia, lebih dari itu yakni menginformasikan berbagai dunia yang ada. Sementara menurut perspektif kaum marxisme mayoritas akan menuntut pada dalih media menawarkan tambahan melalui kontemplasi, terhadap relasi sosial, yang terlaksana dalam wadah yang menyimpang. Dalam sistem kelas, umumnya karakter 'sejati' bermula dari keterkaitan sosial, kuasa dan ketidakadilan, merupakan kesalah pahaman. Dalam sistem kelas harta dialokasikan jauh dari pembuatnya, akan tetapi proses menjadi urgent, proses tersebut dikaburkan dalam beragam metode. Salah satunya dengan kepemilikan dan kontrol atas media broadcast yang menggelobal. ${ }^{19}$

Munculnya Sensai media sosial mampu memberikan pelunturan kebangsaan dikarenakan banyaknya media tidak mampu memberitakan bangsa secara baik umumnya siaran mereka demi menigkatkan rating dan sensasi, bukan meningkatkan semangat kebangsaan sehingga seringkali terjadi hate speech dan kerusakan umat khususnya bagi umat Islam sebagai mayoritas di Indonesia. Narasi perpecahan dengan bentuk hate speech dan sebagainya telah masuk dalam ranah generasi muda penerus bangsa permasalahan tersebut tidak bisa diabaikan. Dibutuhkan implementasi cinta bangsa dan tanah air, sebagai wujud dari iman. Secara garis besar, roh kebangsaan merupakan satu permasalahan yang penting dalam dinamisasi kebebasan yang belum mampu diabaikan, kendatipun mereka belum mencintainya. Kehadiran setiap perjuangan yang bersangkutan dengan bangsa dan tanah air tidak dapat disangkal lagi. Riwayat dunia telah memberikan bukti bahwa bangsa yang bergerak dalam kemerdekaannya, cita-cita kepada internasionalisme kalah oleh semangat kebangsaan. ${ }^{20}$

Media dapat merupakan senjata dalam merusak hubungan, ${ }^{21}$ pada mulanya media cetak merupakan media yang digemari dan banyak digandrungi akan tetapi pelan-pelan mulai bergeser dengan semakin masifnya produksi smart phone, produksi masal smart phone menjadi awalmula meledaknya penggunaan media berbasis teknologi (online), definisi media sosial terdiri dari 2 kata yakni; "media" dan "sosial". "Media" diartikan sebagai perlengkapan interaksi sedangkan kata "sosial" diartikan sebagai realitas sosial bahwa setiap pribadi melakukan tindakan yang memberikan dampak pada masyarakat. Penjelasan

\footnotetext{
${ }^{19}$ David Holmes, 55.

${ }^{20}$ Mohammad Hatta, Demokrasi Kita Pikiran-pikiran Tentang Demokrasi dan Kedaulatan Rakyat (Bandung: Sega Arsy, 2014), 14.

${ }^{21}$ Sejarah mencatat media turut berkontribusi dalam menimbulkan perpecahan baik dalam bidang sosial, ekonomi, agama, dan budaya. Salah satunya perang dunia pertama dan kedua yang menjadi peperangan besar sepanjang sejarah manusia. Media turut memberitakan banyak profokasi dan opini para pakar dalam mendukung maupun kontra dengan berbagai kebijakan pemerintah yang dibuat di era tersebut.
} 
tersebut menandaskan sesungguhnya, media dan perangkat lunak merupakan "sosial" atau pada artian bahwa keduanya merupakan hasil dari sistem sosial.

Dalam perkembangannya media sosial memberikan perubahan budaya dan tatanan yang baru, sebut saja salah satu contohnya selfie, Selfie dapat dimanifestasikan sebagai ajang sosialita dalam aktivitas memperlihatkan diri kepada dunia secara bebas dan bersifat terbuka baik kepada teman atau orang yang belum dikenal. Kata selfie telah diadopsi dan dicantumkan dalam kamus Oxford English Dictionary tahun 2013 secara ringkas berarti foto yang disalurkan melalui "media sosial". 22

Selfie merupakan aktualisasi seseorang melalui media, di mana pelaku merasakan nilai kepuasan ketika melakukan posting swafoto yang dimilikinya untuk disebarluaskan ke ranah umum. Ada beberapa ulasan yang bisa dipaparkan mengenai selfie dalam lensa psikologi sosial. Pertama, usaha tersebut merupakan bentuk eksistensi diri yang diaplikasikan sebagai swafoto dan mengabarkannya melalui media sosial bukan sekedar fokus pada pencitraan di media sosial, melainkan upaya yang dinilai hadir dalam jaringan. Swafoto sukses jika apa yang di posting mendapat pujian dan apresiasi dari khalayak nitizen dalam Facebook pemberian like atau love sedangkan di Instagram ditandai dengan tanda love dengan $2 \mathrm{x}$ menekan foto tersebut. ${ }^{23}$

Kedua, swafoto ialah salah satu narsisme digital sebuah swafoto yang diambil memperlihatkan bahwa pelakunya sedang mempersiapkan dirinya dan hasilnya, memperlihatkan reaktualisasi diri, serta menjadi pertunjukan di depan media demi mengait penonton dari pengguna media lainnya pada pertemanan media sosial. Ketiga, swafoto menandai pelakunya terbuka dan update di media sosial. Disadari dengan hadirnya budaya swafoto seringkali dapat meningkatkan tendensi masal sebab apa yang di posting tidak menunjukan nilai kebaikan yang berujung pada ujaran kebencian dan perpecahan bangsa. ${ }^{24}$

Kehadiran media mainstream juga turut merubah wajah Islam Indonesia sehingga Islam lebih dinamis dan tidak statis. Dengan munculnya berbagai aliran dakwah yang luwes (moderat) dan kaku, menjadi tantangan Islam kedepannya. Masalah kontemporer mulai masuk dalam kehidupan manusia, baik yang ada di kota dan desa pengaruh tuntutan zaman mendorong semakin gencar memperturutkan aliran perubahan, baik usia tua, remaja dan anak-anak. Dakwah

\footnotetext{
22 Mulawarman, Aldila Dyas Nurfitri, 36.

${ }^{23}$ Akan tetapi dalam perjalanannya makna selfi terkadang menyesuaikan konteksnya. Selfi juga merupakan bentuk mengekpresikan identitas seperti halnya akun dalam media sosial tentu terdapat foto pemilik akun yang menjadi penanda bahwa akun tersebut resmi milik sesorang. Sehingga tidak terkesan memunculkan aneka tafasir yang berkonotasi negatif seperti akun palsu atau akun spam yang memberikan pengaruh buruk.
}

24 Mulawarman, Aldila Dyas Nurfitri, 38. 
modern ialah dakwah yang mengaplikasikan teknologi modern berdasarkan tiga indikator, yaitu; da'i yang modern, materi dakwah yang modern dan da'i yang menggunakan teknologi. ${ }^{25}$

Timbulnya era pos-Islamisme menghadirkan besarnya peran media, seringkali sensasi yang dihadirkan media digunakan untuk memadukan idealisme untuk meraih animo publik. Dalam ruang transisi pertemuan lokal dan global, subjek diajak untuk mengeksplorasi bentuk baru interpretasi agama yang dihubungkan dengan hak-hak individu. Pos-Islamisme sebagai proyek transformasi Islamisme untuk bangkit dan menggerakkan massa platform ideologisnya, pada ruang yang lain menyisakan skeptitisme bagi ragam Islam yang lain semisal tradisionalis dan post-tradisionalis. ${ }^{26}$

Kehadiran media mainstream dapat memberikan perubahan sosial, masyarakat dengan bebas mengakses yang diinginkan dan menghasilkan interaksi yang urgent pada ruang publik. Ruang publik yang dimaksud selaras dengan Hubermas yakni dengan hadirnya lembaga informasi yang mengarah pada media massa dan berfungsi sebagai informasi pada masyarakat dan penunjang kebutuhan umum. Ruang massa dapat diciptakan pasca demokratisasi dan perubahan teknologi sehingga tidak saja melahirkan kebebasan pers, tetapi memberikan rangsangan pada khalayak agar mengemukakan dengan cepat melalui Citizen Journalism, membuat informasi jadi milik bersama. Milik bersama bermakna, jurnalisme tidak hanya dimonopoli media-media raksasa lagi, akantetapi oleh khalayak biasa. Khalayak mampu menyalurkan informasi melalui alat-alat yang dimilikinya. ${ }^{27}$

Hadirnya media mainstream tidak lepas dari kepentingan, sebab media dijadikan kendaraan untuk menyalurkan aspirasi dari masing-masing mereka yang berkepentingan. Dalam pandangan pluralis media terlihat sebagai ruang bebas dan bukan menjadi ajang sensasi bagi kelompok-kelompok masyarakat dengan menyalurkan kebutuhan kolektif tanpa hadrinya monopoli. Akan tetapi dalam prespektif cerdas, media tidak lain hanya sebagai penyalur dominasi kelompok untuk menekan kelompok lain. Dua pandangan tersebut mempermasalahkan

${ }^{25}$ Fahrurrozi, Model-Model Dakwah Di Era Kontemporer (Strategi Merestorasi Umat Menuju Moderasi dan Deradikalisasi) (Mataram: LP2M UIN Mataram, 2017), 5.

26 Dien Vidia Rosa, Hery Prasetyo, "Perempuan Islam dan Interpretasi PosIslamisme Artikulasi dan Praktik Ruang Dalam Media," in Islamisme dan Post-Islamisme dalam Dinamika Politik Indonesia Kontemporer (Yogyakarta: Suka-Press dan CISForm, 2019), 159.

${ }^{27}$ Munculnya media mainstream tidak hanya dimaknai dengan dampak yang negatif, akan tetapi munculnya media mainstream juga mampu memberikan dorongan kepada masyarakat yang ingin mengungkapkan ekspresi dan kebebasan pers. Dalam media tersebut seseorang bebas memberikan kritik dan tanggapan positif. Sehingga terkadang menciptakan suasana diskusi akan tetapi tidak banyak pula yang memberikan suasana tidak baik dan berujung pada pelaporan kepada pihak yang berwenang. 
filosofi media, dan relasi antar media, serta hadirnya media di lingkungan masyarakat. ${ }^{28}$

\section{Konsep Sosial Umat Islam}

Konsep sosial Islam memiliki jangkauan yang luas dari konsep pengentasan kemiskinan, konsep aktualisasi dan harmonisasi kerukunan baik sesama maupun berbeda keyakinan, dan sebagainya. Konsepsi tersebut dibingkai menjadi konsep sosial Islam. Islam, merupakan agama yang lengkap dan universal. Kemiskinan ialah problem sosial yang diperhatikan oleh Islam. Islam mengangkat tema dalam upaya pemberdayaan dalam mengentas kemiskinan, menurut research yang dilakukan Muhammad Istan kemiskinan terbagi menjadi 3 jenis;

1. Kemiskinan Natural, kemiskinan yang terjadi akibat alam. Akan tetapi dalam konsep kemiskinan tersebut baik Istan maupun peneliti sendiri tidak sependapat sebab ada daerah yag tandus akan tetapi makmur seperti di Timur Tengah yang disebabkan minyak.

2. Kemiskinan Kultural, kemiskinan yang disebabkan dari intern, maksudnya budaya seseorang yang membuat dirinya miskin. Dalam sifat manusia ada sifat yang membuatnya kaya demikian pula ada sifat yang menjadikan orang tersebut miskin.

3. Kemiskinan Struktural, kemiskinan yang disebabkan kurangnya kemudahan dalam sumber daya yang terjadi dalam sebuah sistem sosial, budaya, dan politik yang tidak menerima kemiskinan. ${ }^{29}$

Faktanya, kemiskinan menjadi salah satu faktor $\mathrm{X}$ individu atau kelompok melakukan perpecahan dengan menyebarkan kabar hoaks, dan ujaran kebencian, di lapangan sendiri sering ditemui berbagai adu argumen mengenai sumber yang belum jelas faktanya, yang semuanya hanya dilandaskan dengan material. ${ }^{30}$ Berdasarkan data dari BPS (Badan Pusat Statistik), ekonomi Indonesia Triwulan II-2020 turun 5,32\%. Sedangkan berdasarkan besaran Produk Domestik Bruto (PDB) atas dasar harga berlaku triwulan II-2020 mencapai Rp 3.687,7 triliyun dan atas dasar harga konstan 2010 mencapai Rp 2.589,6 triliyun. Perkembangan lapangan usaha pada kuartal II 2020 menurun dibanding kuartal I dalam datanya bahwa transportasi dan perdagangan anjlok sebanyak -30,84\%,

${ }^{28}$ Yanti Dwi Astuti, "Eksistensi Public Sphere Dalam Media Mainstream: Studi Pada Rubrik Citizen Journalism Tribun Yogyakarta," Jurnal Sosiologi Reflektif, Vol. 12, No. 2, (2018): 237, https://doi.org/10.14421/jsr.v12i2.1235.

29 Muhammad Istan, "Pengentasan Kemiskinan Melalui Pemberdayaan Ekonomi Umat Menurut Persfektif Islam", Al-Falah: Journal of Islamic Economics," Vol. 2, No 1. (2017): 83, http://journal.iaincurup.ac.id /index.php/alfalah/article/view/199.

${ }^{30}$ Ibid., 84. 
sektor jasa dan kegiatan sosial menurun menjadi 3,71\% hanya surplus pada sektor informasi dan komunikasi. Dengan demikian tidak menutup peluang bahwa ajang informasi dan komunikasi menjadi ladang subur untuk kegiatan mengais rezeki baik secara positif seperti ajang bisnis atau negatif seperti melontarkan hate space dan hoaks semata. ${ }^{31}$

Pascareformasi hubungan sosial umat Islam bukan bertambah baik, banyak terjadi kemerosotan yang ditandai dengan merebaknya globalisasi, apalagi ditambah dengan revolusi industri 4.0. Pancasila hanya sekedar slogan dan belum diimplementasikan secara menyuluruh, secara langsung jika Islam melemah akan berimbas pada ketahanan nasional sebab mayoritas bangsa Indonesia beragama Islam, ketahanan nasional merupakan kondisi dinamis yang mengintegrasikan dari segenap sendi kehidupan bangsa dan negara. Sejatinya ketahanan nasional adalah menjamin kelangsungan hidup menuju kejayaan bangsa dan negara. ${ }^{32}$

Kehadiran Islam di Indonesia mampu memberikan aktualisasi dan harmonisasi kerukunan baik dalam satu komunitas agama yang sama atau berbeda, dalam survei yang dilakukan Wahid Foundation yang dilansir dalam republika.co.id pada 19 Januari 2020 menghasilkan sebanyak 0,4\% WNI pernah melakukan tindakan radikal. Tindakan radikal di Indonesia semakin meningkat dipengaruhi beberapa faktor seperti tendensi politik, ceramah, dan pidato yang bermuatan ujaran kebencian, serta postingan bermuatan ujaran kebencian di media sosial. 0,4\% dari populasi Indonesia ialah 600.000 dan dihitung berdasarkan penduduk dewasa sebanyak 150.000 .000 jiwa. Adapula masyarakat yang berkesempatan melakukan radikal jumlahnya sekitar 11,4 juta jiwa atau 7,1\%. Terjadi peningkatan dalam intoleransi dari 46\% menjadi 54\%.33

Meningkatnya penggunaan media sosial, mampu memberikan perubahan sosial yang ada, dengan dukungan globalisasi terjadi pembiasan kebudayaan dan menumbuhkan rasa hedonisme dan perilaku maskulinitas khususnya di kalangan milenial, life style hedon menjadi bentuk hidup yang sesuai dan didasarkan pada aktivitas yang berfokus pada bermain dan membuang waktu di luar rumah, membelanjakan barang mahal, serta menjadi pusat perhatian. Perilaku hedonis pemuda cenderung menghindari percakapan yang dianggap

\footnotetext{
${ }^{31}$ Data BPS, "Pertumbuhan Ekonomi Indonesia Triwulan II-2020”, “no. 64/08/Th. XXIII,".

32 Samsul Wahidin, 133.

33 Nidia Zuraya, "Radikalisme dan Intoleransi Cenderung Menigkat di Indonesia", https://www.google.com/amp/s/m.republika.co.id/amp/q4b95k383, Diakses pada 17 Desember 2020 .
} 
tidak sesuai dengan mileniarisme, serta lebih mengagumi pemabahasan terkait masalah model, dan perilaku hedon lainnya. ${ }^{34}$

Perpecahan yang terjadi dalam tubuh umat Islam telah memberikan dampak besar bahkan bagi integritas Indonesia, banyak politisi Islam dan masyarakat Islam yang tidak peduli terhadap kehidupan saudara yang di luar kalangan sosial mereka meski sesama Muslim. Banyak pula pejabat-pejabat muslim yang korupsi disaat bangsa ini sedang berjuang melawan Covid-19. Diperparah permasalahan Papua Merdeka, maka dibutuhkan peran strategis pemerintah dan intelektual, yakni dengan melakukan penguatan ekonomi dan reaktualisasi nilai-nilai harmoni serta penguatan karakter kebangsaan dengan warga negara yang baik. Kesadaran Pemerintah dan intelektual menciptakan terbentuknya perubahan-perubahan ke arah yang lebih baik, sehingga menciptakan evaluasi yang tepat dari arah yang sejalan dengan kepentingan rakyat kapasitas tersebut tergantung mutu pemerintah dan cendekiawancendekiawan serta keluasan minat mereka. ${ }^{35}$

Pembangunan harmonisasi dan dialog diperlukan untuk mencegah perpecahan bangsa proyek pembangunan kehidupan harmoni dan toleransi diantara Islam dan antar agama didukung oleh pemerintah di bawah konteks integrasi nasional. Secara spesifik menciptakan stabilitas dalam mendukung pembangunan nasional. Selain itu sebagai sebuah masyarakat yang majemuk diperlukan perhatian mengenai nilai inklusif dan pluralis. Dengan aktualisasi harmonisasi mampu meminimalisir efek buruk tertutupnya pemikiran, para intelektual dapat berperan untuk mendorong kegiatan tersebut dikala maraknya hoaks dan ujaran kebencian yang menerpa Indonesia, seperti dengan menyelenggarakan forum, dan penyuluhan guna mencari titik temu bersama, dan masih banyak lagi cara yang dapat dilakukan demi kebaikan umat dan bangsa. ${ }^{36}$

Peran pendidik dan orang tua besar dalam melindungi generasi muda dari demoralisasi, akan tetapi dalam praktiknya terjadi ketimpangan antara teori dan praktik, terdapat semangat Islam yang belum disentuh. Sehingga mengkaburkan definisi pendidikan itu sendiri yakni proses merubah perilaku individu, di masyarakat dan sekitarnya dengan pembelajaran sebagai aktivitas asasi dan profesi asasi di masyarakat, adapun pendidikan karakter yang lebih humanis sehingga diharapkan mampu mewujudkan slogan pendidikan, serta

34 Sri Wahyuningsih and Ardian Adi Putra, "Intensitas Penggunaan Media Sosial Instagram dengan Gaya Hidup Hedonis Pada Remaja," Jurnal Psikologi, Vol. 3, No. 2 (2020): 113.

35 Soejadmoko, "Peran Intelektual Negara Sedang Berkembang," in Cendekiawan dan Politike (Jakarta: LP3ES, 1983) 46.

36 Zainun Kamal et al., Interfaith Theology Responses of Progressive Indonesian Muslims (Jakarta: ICIP, 2006), 127-129. 
penting untuk dikaji di era teknologi, tujuan pendidikan karakter yakni; 1. Sebagai pengembangan potensi untuk memberikan wawasan dan contoh yang lebih baik, 2. Memperkuat kiprah pendidikan nasional dengan menumbuhkan semangat tanggung jawab dan minat siswa atau peserta didik, 3. Sebagai penyaring kebaikan dan keburukan, tanggung jawab tersebut tidak bisa diabaikan di tengah pusaran westernisasi semakin deras, dari luar bangsa yang masuk ke dalam sehingga merubah perilaku dan budaya generasi muda. ${ }^{37}$

Tujuan Pendidikan Islam ialah merealisasikan kekhasan Islam. Sedangkan dalam kandungannya kekhasan Islam termanifestasikan pada perilaku manusia yang berlandaskan Iman dan Taqwa pada Allah. Adapun kehidupan yang mengandung nilai keislaman dapat dikategorikan dalam tiga kategori; 1 . Menguatkan kesejahteraan kehidupan manusia di dunia agar mereka menggunakan kehidupan dunia sebagai sarana menuju akhirat, 2. Menyeru manusia memperoleh kebahagiaan akhirat tidak terkekang oleh materi duniawi, 3. Meyelaraskan kehidupan dunia dan akhirat agar tidak terperdaya dari masalah dunia dalam konteks spiritual, sosial, dan individu. ${ }^{38}$

Pembelahan Islam dewasa ini memunculkan sikap keakuan dan ego sentrisme yang berujung pada lunturnya persatuan Indonesia dan semangat berkeadaban yang menghargai sesama serta berbudi luhur, melihat keumuman pada media sosial umat Islam saling mencaci dan memaki khususnya pasca pemilu 2014 dan 2019 dengan sebutan yang kasar dan tidak pantas, seperti; Cebong, Kadrun (Kadal Gurun), Kampret, Banserep, Bani Serbet, Kaum Sumbu Pendek, dan masih banyak lagi ucapan yang tidak sesuai. Pembiaran tersebut menjadikan prasangka dan perpecahan, dengan timbulnya fitnah, dalam praktik tersebut media memainkan peran penting. Media massa merupakan hasil cipta manusia yang selalu berkembang. ${ }^{39}$

Sebagaimana kasus kemerdekaan Timor-timor media masa dan LSM luar negeri khususnya Australia, Portugis, dan Amerika bekerjasama memposisikan Indonesia sebagai negara penjajah dan tidak bisa dalam menangani Timor-timor, sedemikian ramainya penetrasi global meningkatkan ancaman integritas dan lunturny nilai kebangsaan Indonesia berada persilangan jalan tidak pernah sempat berkembang tanpa pengaruh dan gangguan dari luar. ${ }^{40}$ Indonesia sudah berusaha dengan baik dengan memberikan fasilitas yang terbaik

37 Abd Hamid Wahid, Chusnul Muali, and Kholifatur Rafikah Qodratillah, "Pengembangan Karakter Guru Dalam Menghadapi Demoralisasi Siswa Perspektif Teori Dramaturgi," Jurnal Mudarrisuna: Media Kajian Pendidikan Agama Islam, Vol. 8, No. 1, (2018): 107, https://doi.org/ 10.22373/jm.v8i1.2792.

38 Abd Hamid Wahid, Chusnul Muali, dan Kholifatur Rafikah Qodratillah, 108.

39 Yudi Latif, Wawasan Pancasila Bintang Penuntun Untuk Pembudayaan Edisi Revisi (Bandung: Mizan, 2020).

40 Ibid., 5. 
di masa itu, memberikan anggaran yang lebih, dan kebebasan beragama yang ditandai dengan dibangunnya patung Yesus di atas bukit setinggi 27 meter yang bersimbol bahwa Timor-timor menjadi provinsi ke 27 Indonesia, tetapi media masa memberitakan keburukan Indonesia dan hasilnya Timor-timor lepas. Pada hakikatnya terjadi pengalihan isu agar saling memusuhi sesama oleh asing melalui media yang membuat hoaks dan hatespeech, diperparah dengan isu-isu pelanggaran HAM yang dilontarkan asing pada Indonesia dalam forum-forum internasional.

Globalisasi memunculkan tersebarnya iklan-iklan westernisasi, banyak iklan-iklan yang menggambarkan Barat dan kemajuannya dengan meletakkan nilai agama dalam konsepsi tersebut memunculkan bahwa keadaan tersebut memberikan ketertarikan pada golongan muda, dengan dalih trend dan modis sehingga muncul persepsi bila tidak ikut maka akan ketinggalan. Keadaan tersebut disebut framing media, Robert $\mathrm{N}$ Entman menjelaskan model framing digunakan untuk mengetahui relitas yang terjadi di lapangan dan bagaimana kita menafsirkan relitas tersebut ke dalam konten. Entman melihat framing dalam dua dimensi besar, yakni; seleksi isu dan penekanan penonjolan aspek-aspek tertentu. ${ }^{41}$

Kemunculan hoaks dan perpecahan mampu meningkatkan tendensi politik, sebagaimana servei yang dilakukan kembaga Riset PolMark Indonesia menyebut retaknya kerukunan sosial disebabkan pemilu beruntun mulai Pemilu Presiden 2014, Pemilu Gubernur Jakarta 2017, Pemilihan Kepala Daerah 2018, dan Pemilu Presiden 2019. Tercatat 5,7\% informan merasa Pilihan Gubernur DKI Jakarta telah merusak hubungan pertemanan. Angka tersebut meningkat dibandingkan dengan 2014, sebanyak 4,3\% informan memandang Pilihan Presiden memberikan kerusakan relasi pertemanan di masyarakat. Uniknya kejadian tersebut disebarkan melalui media mainstream yang membuat kerusakan dalam masyarakat. ${ }^{42}$

Media juga berperan dalam menyebarkan berita dan masih hangat dengan tergoncangnya video seruan "hayya alal jihad" dalam adzan. Akhirnya Polda Metro Jaya menangkap tersangka penyebar video tersebut, polisi mengungkap bahwa tersangka berprofesi sebagai kurir di sebuah perusahaan swasta di Jakarta, menurut Kabid Humas Polda Metro Jaya Yusri Yunus, tersangka $\mathrm{H}$ mendapatkan rekaman video itu dari group whatsapp bernama FMCO News (Form Muslim Cyber One), diketahui tersangka bergabung di grup tersebut

41 Ardhina Pratiwi, "Konstruksi Realitas Dan Media Massa (Analisis Framing PEMBERITAAN LGBT Di Republika Dan BBC News Model Robert N. Entman)," Thaqafiyyat: Jurnal Bahasa, Peradaban dan Informasi Islam, Vol. 19, No. 1, (2018): 55.

42 Toni Ervianto, "Residu Pemilu 2019: Politik Identitas dan Polarisasi Masyarakat", https://www.dekadepos.com/residu-pemil-2019-politik-identitas--dan-polarisasimasyarakat/, Diakses pada 18 Desember 2020.. 
sejak 2017. Menurut Yusri tersangka menyebarkan melalui akun Instagram pribadi@hashophasan. Dalam narasi video tersebut, tertulis seruan sebagai respon beberapa warga atas pemanggilan Habib Rizieq Shihab oleh polisi terkait kasus kerumunan masa di Petamburan. FPI memberikan respon terkait video tersebut yang diwakili oleh Wakil Sekertaris Umum Front Pembela Islam (FPI) Aziz Yanuar yang menuturkan "seruan untuk jihad itu tidak hanya di Petamburan, Jakarta Pusat, akan tetapi juga di beberapa tempat lain". ${ }^{43}$ Secara tidak langsung media mempertontonkan kejadian dan dinilai oleh public sehingga tidak menutup kemungkinan dalam waktu yang dekat juga dapat melatar belakangi terciptanya simpatisan dan kerumunan massa.

\section{Penutup}

Berdasarkan hasil penelitian tentang konektivitas Hate Speech, Hoaks, Media Mainstream dan Pengaruhnya Bagi Sosial Islam Indonesia, bahwasannya hadirnya media turut memberikan perubahan dalam nalar dan perilaku masyarakat dalam kehidupan sehari-hari. Fakta tersebut diawali dengan timbulnya berita hoaks, kemudian bermetamorfosa menjadi Hate Speech yang disalurkan melalui media mainstream baik berbentuk cetak maupun melalui media tayang yang berbentuk siaran televisi maupun media sosial, seperti; Facebook, dan Instagram. Pada titik ini muncul kekuatan framing yang dilakukan media bagaimana menggiring opini masyarakat agar nalar mereka termakan berita yang belum tentu ada faktanya, oleh sebab itu dibutuhkan pendidikan bermedia sosial dan pendidikan yang berorientasi pada pembangunan sosial yang mengedepankan kepekaan sosial guna meminimalisir pengulangan kesalahan kembali.

Peran pemerintah, intelektual, dan pemuka agama dibutuhkan guna memberikan sokongan dan dorongan khususnya umat Islam dalam menghadapi globalisasi teknologi, perkembangan teknologi memberikan dampak positif yakni semakin mudahnya akses masyarakat dalam mendapatkan informasi dan memudahkan efisiensi birokrasi akan tetapi disisi lainnya yakni menyebarnya berita hoaks, media mainstream, dan tantangan persatuan bangsa. Perpecahan tersebut tercermin dari munculnya julukan-julukan yang buruk seperti cebong, kadrun, kampret, bani serbet, kaum sumbu datar, dan lainnya. Kemunculan pos Islamisme menjadi salah satu pendorong antusiasisme masyarakat, serta menghasilkan pembentukan politik identitas melalui media mainstream dengan menayangkan isu-isu terkini demi meraih animo publik secara masal.

${ }^{43}$ Yogi Ernes, “Tersangka Penyebar Video Azan 'Hayya alal Jihad' Seorang Kurir,”, https://news.detik.com/berita/d-5280265/tersangka-penyebar-video-azan-hayya-alal-jihadseorang-kurir/2, Diakses pada 09 Desember 2020. 


\section{Daftar Pustaka}

Abdullah, Amin. "Hermeneutika Islam Dan Budaya Populer.” In Kitab Suci dan Para Pembacanya, 1st ed., 19-30. Yogyakarta: Stelkendo Kreatif, 2019.

Astrika, Lusia, and Yuwanto Yuwanto. "Ujaran Kebencian dan Hoaks: Signifikasinya terhadap Pemilih Pemula di Kota Semarang." JIIP: Jurnal Ilmiah Ilmu Pemerintahan.Vol. 4, No. 2 (2019).

Astuti, Yanti Dwi. "Eksistensi Public Sphere Dalam Media Mainstream: Studi Pada Rubrik Citizen Journalism Tribun Yogyakarta." Jurnal Sosiologi Reflektif, Vol. 12, No. 2 (2018).

BPS, "Pertumbuhan Ekonomi Indonesia Triwulan II-2020", “no. 64/08/Th. XXIII,"

Ernes, Yogi. “Tersangka Penyebar Video Azan 'Hayya alal Jihad' Seorang Kurir”, https://news.detik.com/berita/d-5280265/tersangka-penyebar-video-azanhayya-alal-jihad-seorang-kurir/2. (Diakses pada 09 Desember 2020.

Ervianto, Toni. "Residu Pemilu 2019: Politik Identitas dan Polarisasi Masyarakat", https://www.dekadepos.com/residu-pemil-2019-politik identitas-danpolarisasi-masyarakat/. (Diakses pada 18 Desember 2020).

Fahrurrozi. Model-Model Dakwah Di Era Kontemporer(Strategi Merestorasi Umat Menuju Moderasi dan Deradikalisasi). Mataram: LP2M UIN Mataram, 2017.

Hadi, Sofyan. Ilmu Dakwah Dari Konsep Paradigma Hingga metodologi. Jember: Center For Society Studies, 2012.

Hatta, Mohammad. Demokrasi Kita Pikiran-pikiran Tentang Demokrasi dan Kedaulatan Rakyat. Bandung: Sega Arsy, 2014.

Herawati, Dewi Maria. "Penyebaran Hoax Dan Hate Speech Sebagai Representasi Kebebasan Berpendapat." Promedia (Public Relation Dan Media Komunikasi), Vol. 2, No. 2 (2016).

Holmes, David. Teori Komunikasi Media, Teknologi, dan Masyarakat. Yogyakarta: Pustaka Pelajar, 2012.

Istan, Muhammad. "Pengentasan Kemiskinan Melalui Pemberdayaan Ekonomi Umat Menurut Persfektif Islam". Al-Falah: Journal of Islamic Economics, Vol. 2, No. 1 (2017). 
Ningrum, Dian Junita, Suryadi, Dian Eka Chandra Wardhana. "Kajian Ujaran Kebencian Di Media Sosial", Jurnal Ilmiah Korpus, Vol. II, Nomor III (2018).

Kamal, Zainun, Nurcholis Madjid, Masdar F Mas'udi, Komaruddin Hidayat, Budhy Munawar Rachman, Kautsar Azhari Noer, Zuhairi Misrawi, and Ahmad Gaus AF. Interfaith Theology Responses of Progressive Indonesian Muslims. Jakarta: ICIP, 2006.

Latif, Yudi. Wawasan Pancasila Bintang Penuntun Untuk Pembudayaan Edisi Revisi. Bandung: Mizan, 2020.

Mulawarman, Aldila Dyas Nurfitri. "Perilaku Pengguna Media Sosial beserta Implikasinya Ditinjau dari Perspektif Psikologi Sosial Terapan." Buletin Psikologi, Vol. 25, No. 1 (2017).

Pradewi, Bintang, and Sabik Aji Taufan. "Kasus Hoax dan Hate Speech Covid-19, Polisi: Motifnya Buat Resah Warga," https://www.google.com/amp/s/ www.jawapos.com/nasional/hukum-kriminal/05/05/2020/kasus-hoaxdan-hate-speech-covid-19-polisi-motifnya-buat-resahwarga/\%3famp..(Diakses Pada 05 Desember 2020).

Pratiwi, Ardhina. "Konstruksi Realitas Dan Media Massa (Analisis Framing Pemberitaan LGBT Di Republika Dan BBC News Model Robert N. Entman)." Thaqafiyyat: Jurnal Bahasa, Peradaban dan Informasi Islam Vol. 19, No. 1 (2018).

Pureklolon, Thomas Tokan. Komunikasi Politik Mempertahankan Integritas Akademisi, Politikus, dan Negarawan. Jakarta: Gramedia, 2016.

Rosa, Dien Vidia, and Hery Prasetyo. "Perempuan Islam dan Interpretasi PosIslamisme Artikulasi dan Praktik Ruang Dalam Media." In Islamisme dan Post-Islamisme dalam Dinamika Politik Indonesia Kontemporer. Yogyakarta: SukaPress dan CISForm, 2019.

Soejadmoko. "Peran Intelektual Negara Sedang Berkembang." In Cendekiawan dan Politik. Jakarta: LP3ES, 1983.

Soyomukti, Nuraini. Komunikasi Politik Kudeta Media Analisa Komunikasi Rakyat \& Penguasa. Malang: Intrans Publishing, 2013.

Wahid, Abd Hamid, Chusnul Muali, and Kholifatur Rafikah Qodratillah. "Pengembangan Karakter Guru Dalam Menghadapi Demoralisasi Siswa Perspektif Teori Dramaturgi." Jurnal Mudarrisuna: Media Kajian Pendidikan Agama Islam, Vol. 8, No. 1 (2018). 
Wahidin, Samsul. Dasar-Dasar Pendidikan Pancasila dan Pendidikan Kewarganegaraan. Yogyakarta: Pustaka Pelajar, 2018.

Wahyuningsih, Sri, and Ardian Adi Putra. "Intensitas Penggunaan Media Sosial Instagram dengan Gaya Hidup Hedonis Pada Remaja." Jurnal Psikologi, Vol.3, No. 2 (2020).

Zuraya, Nidia. "Radikalisme dan Intoleransi Cenderung Menigkat di Indonesia," https://www.google.com/amp/s/m.republika.co.id/amp/q4b95k383. (Diakses pada 17 Desember 2020). 